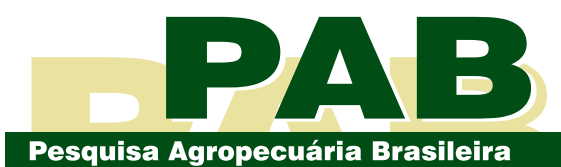

ISSN 1678-3921

Journal homepage: www.embrapa.br/pab

For manuscript submission and journal contents, access: www.scielo.br/pab

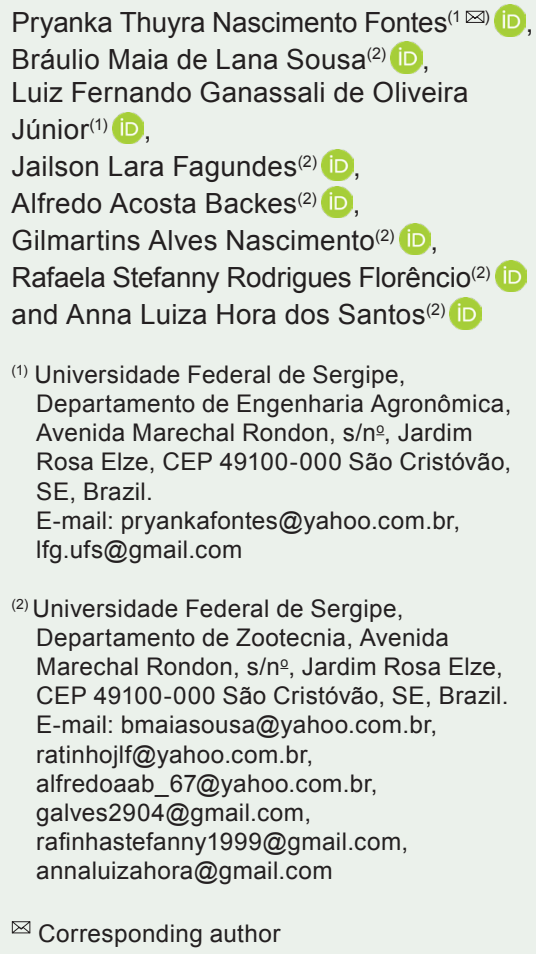

Pryanka Thuyra Nascimento Fontes ${ }^{(1 凶)}(\mathrm{D}$, Bráulio Maia de Lana Sousa(2) (ID, Luiz Fernando Ganassali de Oliveira Júnior $^{(1)}(\mathbb{D}$,

Jailson Lara Fagundes(2) (D),

Alfredo Acosta Backes ${ }^{(2)}$ (ID,

Gilmartins Alves Nascimento(2) (DD, Rafaela Stefanny Rodrigues Florêncio(2) (iD and Anna Luiza Hora dos Santos ${ }^{(2)}$ (iD)

(1) Universidade Federal de Sergipe, Departamento de Engenharia Agronômica, Avenida Marechal Rondon, s/no ${ }^{\circ}$, Jardim Rosa Elze, CEP 49100-000 São Cristóvão, SE, Brazil.

E-mail: pryankafontes@yahoo.com.br, Ifg.ufs@gmail.com

(2) Universidade Federal de Sergipe, Departamento de Zootecnia, Avenida Marechal Rondon, s/no, Jardim Rosa Elze, CEP 49100-000 São Cristóvão, SE, Brazil. E-mail: bmaiasousa@yahoo.com.br, ratinhojlf@yahoo.com.br, alfredoaab_67@yahoo.com.br, galves2904@gmail.com, rafinhastefanny1999@gmail.com, annaluizahora@gmail.com

$\bowtie$ Corresponding author

Received

August 18, 2019

Accepted

June 30, 2020

How to cite

FONTES, P.T.N.; SOUSA, B.M. de L.; OLIVEIRA JÚNIOR, L.F.G. de; FAGUNDES, J.L.; BACKES, A.A.; NASCIMENTO, G.A.; FLORÊNCIO, R.S.R.; SANTOS, A.L.H. dos. Population dynamics and structural characteristics of 'Survenola' digit grass subjected to intermittent defoliation strategies. Pesquisa Agropecuária Brasileira, v.55, e01602, 2020. DOI: https://doi. org/10.1590/S1678-3921. pab2020.v55.01602.

\section{Population dynamics and structural characteristics of 'Survenola' digit grass subjected to intermittent defoliation strategies}

\begin{abstract}
The objective of this work was to evaluate the effect of defoliation strategies and insolation periods on the population dynamics and structural characteristics of Digitaria eriantha 'Survenola'. The following four defoliation strategies (DSs) were evaluated: 40/10,40/20, 50/10, and 50/20 cm (that is, 40 and $50 \mathrm{~cm}$ pre-defoliation height, and 10 and $20 \mathrm{~cm}$ post-defoliation height), under high- (September to March) and low- (April to August) insolation periods. An experimental randomized complete block design was carried out with five replicates. The accumulation of forage and leaf blade was higher when using the DS $40 / 20 \mathrm{~cm}$ in the higher insolation period. DSs $40 / 10,50 / 10$, and $50 / 20 \mathrm{~cm}$ resulted in a higher stem accumulation than DS $40 / 20 \mathrm{~cm}$. 'Survenola' grass showed a higher appearance rate for basal and aerial tillers using the $40 / 10$ and $40 / 20 \mathrm{~cm}$ strategies, respectively, during the lower insolation period. Greater tiller densities (basal, aerial, and total) were observed in the DS $40 / 20 \mathrm{~cm}$ in the higher insolation period. DS 40/20 cm resulted in a greater tiller renewal. In the DS $40 / 20 \mathrm{~cm}$, 'Survenola' grass shows the greatest number of defoliation cycles, the highest density of tillers, and the greatest accumulation of forage and leaf blade.
\end{abstract}

Index terms: Digitaria eriantha, canopy structure, grass perenniality.

\section{Dinâmica da população e características estruturais do capim 'Survenola' submetido a estratégias de desfolhação intermitente}

\begin{abstract}
Resumo - O objetivo deste trabalho foi avaliar o efeito de estratégias de desfolhação e períodos de insolação sobre a dinâmica populacional de perfilhos e as características estruturais de Digitaria eriantha 'Survenola'. Avaliaram-se as seguintes quatro estratégias de desfolhação (EDs), conforme: $40 / 10,40 / 20,50 / 10$ e 50/20 cm, ou seja, 40 e $50 \mathrm{~cm}$ de altura pré-desfolhação, e 10 e $20 \mathrm{~cm}$ de altura pós-desfolhação, nos períodos de alta (setembro a março) e baixa insolação (abril a agosto). $\mathrm{O}$ delineamento experimental foi realizado em blocos ao acaso, com cinco repetições. Os acúmulos de forragem e lâmina foliar foram maiores quando se utilizou a ED $40 / 20 \mathrm{~cm}$, no período de maior insolação. As EDs 40/10, 50/10 e 50/20 cm resultaram em maior acúmulo de colmo do que a ED 40/20 cm. O capim 'Survenola' mostrou maior taxa de aparecimento de perfilhos basais e aéreos, quando se utilizaram as estratégias 40/10 e 40/20 cm, respectivamente, durante o período de menor insolação. Maiores densidades de perfilhos (basais, aéreos e totais) foram observadas na ED 40/20 cm, no período de maior insolação. A ED 40/20 cm obteve maior renovação de perfilhos. Na ED 40/20 cm, o capim 'Survenola' apresenta o maior número de ciclos de desfolhação, a maior densidade populacional de perfilhos e o maior acúmulo de forragem e lâmina foliar.
\end{abstract}

Termos para indexação: Digitaria eriantha, estrutura do dossel, persistência no pasto. 


\section{Introduction}

'Survenola' digit grass is a perennial forage plant that shows a cespitous and stoloniferous growth with vegetative propagation (Cook \& Schultze-Kraft, 2015). This plant is currently used in pasture systems, especially in the states of Alagoas and Sergipe in the Northeastern Brazil (Souza et al., 2016). This grass is adapted to the region, that shows reduced rainfall and high average temperatures, as well as soils with low natural fertility. Its adaptation to growth in regions with low-water availability comes from its ability to absorb water droplets that are suspended in the air (dew) (Navarro et al., 2005).

Historically, 'Survenola' digit grass has been recommended for low-productivity systems. However, recent studies indicate that 'Survenola' responds well to irrigation and nitrogen fertilizers (Souza et al., 2016), and it can reach a forage production of more than $30 \mathrm{Mg} \mathrm{ha}^{-1}$ of dry mass per year of (Cruz et al., 2019), indicating that white-grass can be used in more intensive production systems. This species shows also crude protein contents between 10 and $15 \%$ (Gusmão Filho, 2018). Therefore, some strategies for the defoliation of 'Survenola' digit grass need still to be defined, in order to improve its pasture systems.

The definition of defoliation strategies should be carried out respecting the inherent characteristics of each forage species. The combination of the pre- and post-defoliation strategies have a significant importance for tiller renovation and grass perenniality (Carvalho et al., 2017), as it promotes changes in the light incidence at the base of the canopy, as well as in the photosynthetic rates of the forage plant and in the stability of the tiller population (Silva \& Nascimento Júnior, 2007). In addition, the maintenance of the residual leaf area, determined by the post-defoliation height, favors the appearance of new tillers and the lengthening of leaf blades due to a greater photosynthetic efficiency (Santos et al., 2014). Thus, determining the residue height of forage grasses is important to identify the adequate management to allow of the maintenance of pasture, and the best growth conditions for the plants. However, for species such as Digitaria eriantha Steud 'Survenola', commonly known as 'Survenola' digit grass, the combination of pre- and post-defoliation strategies are yet to be defined.

The objective of this work was to evaluate the population dynamics and structural characteristics of 'Survenola' digit grass tillers subjected to four defoliation strategies under high and low insolation periods.

\section{Materials and Methods}

The experiment was performed in the municipality of São Cristóvão, in the state of Sergipe (SE), Brazil $\left(11^{\circ} 22^{\prime} \mathrm{S}, 37^{\circ} 12^{\prime} \mathrm{W}\right.$, at $47 \mathrm{~m}$ altitude) from July 2017 to July 2018. The climate is tropical Awa to the Köppen-Geiger's classification, with dry seasons from September to March, and rainy seasons from April to August. The climate data during the experimental period was obtained from a meteorological station at $11.4 \mathrm{~km}$ from the experimental area (Figure 1).
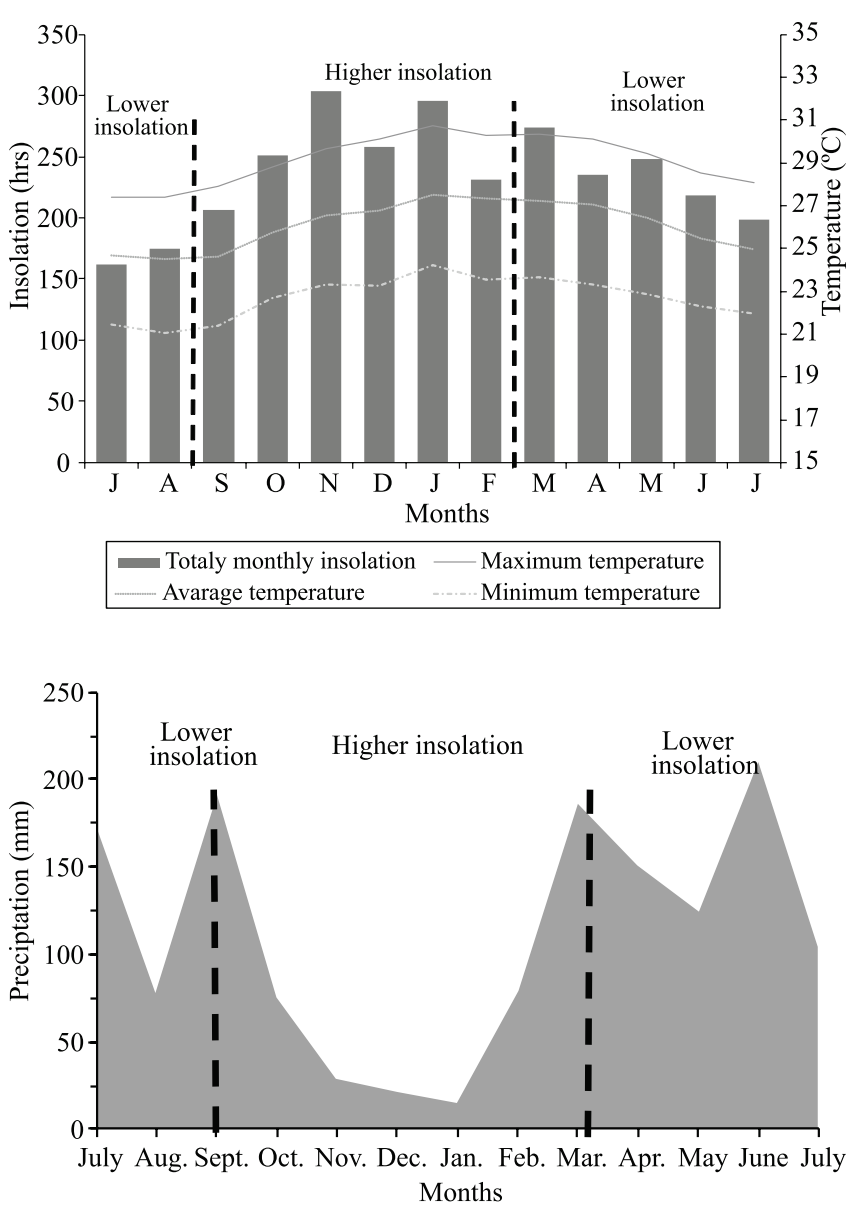

Figure 1. Total monthly insolation (h) and minimum, average, and maximum temperatures (A) and precipitation (B), in the period from July 2017 to July 2018. 
The soil is classified as "Neossolo quartzarênico" (Santos etal., 2018), that is, Entisols(Quartzipsamments) according to the Soil Taxonomy (Soil Survey Staff, 1999), with the following chemical characteristics at 0-20 cm soil depths: $11.8 \mathrm{~g} \mathrm{dm}^{-3}$ organic matter; 6.02 $\mathrm{pH} \mathrm{H}_{2} \mathrm{O} ; 38.65 \mathrm{mg} \mathrm{dm}^{-3} \mathrm{P} ; 6.5 \mathrm{mg} \mathrm{dm}^{-3} \mathrm{Na} ; 6.30 \mathrm{mg}$ $\mathrm{dm}^{-3} \mathrm{~K} ; 2.83 \mathrm{cmol}_{\mathrm{c}} \mathrm{dm}^{-3} \mathrm{Ca} ; 0.85 \mathrm{cmol}_{\mathrm{c}} \mathrm{dm}^{-3} \mathrm{Mg} ;<0.08$ $\mathrm{cmol}_{\mathrm{c}} \mathrm{dm}^{-3} \mathrm{Al} ; 1.44 \mathrm{cmol}_{\mathrm{c}} \mathrm{dm}^{-3} \mathrm{H}+\mathrm{Al} ; 3.73 \mathrm{cmol}_{\mathrm{c}} \mathrm{dm}^{-3}$ sum of bases; $5.17 \mathrm{cmol}_{\mathrm{c}} \mathrm{dm}^{-3}$ cation exchange capacity (CEC); and $72.05 \%$ base saturation (V). The soil samples were collected in May 2017.

During the experimental period, the fertilization was carried out using $300 \mathrm{~kg} \mathrm{ha}^{-1} \mathrm{~N}$ per year as urea, $100 \mathrm{~kg} \mathrm{ha}^{-1} \mathrm{~K}_{2} \mathrm{O}$ per year as potassium chloride, and 100 $\mathrm{kg} \mathrm{ha}^{-1} \mathrm{P}_{2} \mathrm{O}_{5}$ per year as single superphosphate, applied in installments after each cut. As the intervals between defoliation were not fixed, the amount of fertilizer that each plot received, during each growth cycle, was variable. Thus, the $300 \mathrm{~kg} \mathrm{ha}^{-1} \mathrm{~N}$ per year, $100 \mathrm{~kg} \mathrm{ha}^{-1}$ $\mathrm{K}_{2} \mathrm{O}$ per year, and $100 \mathrm{~kg} \mathrm{ha}^{-1} \mathrm{P}_{2} \mathrm{O}_{5}$ per year were divided by the growth periods of the forage plant from July 2017 to July 2018, obtaining the daily amount that should be applied in each paddock. The amount of fertilizer actually applied was obtained by multiplying the daily amount by the regrowth period that occurred in each experimental unit. Therefore, at the end of each experiment, all plots received the same amount of fertilization.

Digitaria eriantha 'Survenola' was planted in July 2014, in a $180 \mathrm{~m}^{2}$ area. From August 2014 to July 2016, the forage plant was irrigated regularly to the field capacity of the soil and managed with intermittent defoliation (Cruz et al., 2019). From August 2016 to February 2017, plants grew freely until reaching approximately $50 \mathrm{~cm}$, and then they were mechanically lowered to $10 \mathrm{~cm}$. From March to June 2017, plants grew up to 40 and $50 \mathrm{~cm}$ height and, then, they were reduced to $10 \mathrm{~cm}$ to adapt to a defoliation treatment. In June 2017, the post-defoliation strategies (10 or $20 \mathrm{~cm}$ ) started. Irrigation was applied regularly to maintain the moisture at field capacity according to Sousa et al. (2019).

Four defoliation strategies (DS) were evaluated: 40/10 (40 $\mathrm{cm}$ pre-defoliation height and $10 \mathrm{~cm}$ postdefoliation height); 40/20 (40 cm pre-defoliation height and $20 \mathrm{~cm}$ post-defoliation height); 50/10 (50 $\mathrm{cm}$ pre-defoliation height and $10 \mathrm{~cm}$ post-defoliation height); and $50 / 20 \mathrm{~cm}$ (50 cm pre-defoliation height and $20 \mathrm{~cm}$ post-defoliation height). The choice of postdefoliation heights was taken in order to characterize a condition with greater forage removal $(10 \mathrm{~cm})$, and another condition with less forage removal (20 $\mathrm{cm})$. The procedures were applied during the higher insolation period (September 2017 to February 2018) and lower insolation period (July and August of 2017 and March 2018 to July 2018) (Figure 1). A randomized complete block experimental design was used, with five replicates per treatment. The usable area of each experimental unit (plot) corresponded to $9 \mathrm{~m}^{2}$ $(3.0 \times 3.0 \mathrm{~m})$.

Canopy height was measured weekly to determine the pre-defoliation condition (40 or $50 \mathrm{~cm}$ height). Five points chosen at random were measured per plot. At each point, the height corresponding to the distance between the soil and the leaf horizon was measured, with the aid of a ruler graduated in centimeters. The height of the canopy corresponded to the average of the five points measured in each plot. When the predefoliation heights of 40 and $50 \mathrm{~cm}$ were reached, 'Survenola' digit grass was mechanically lowered with the aid of pruning shears, to the respective post-defoliation heights of 10 and $20 \mathrm{~cm}$. Therefore, defoliation was carried out in different dates, according to the growth of the forage plant.

Forage accumulation of and the morphological components (leaf blade, stem, and dead forage) were measured whenever plants reached the pre-defoliation heights. For the collection, two sampling frames of $0.70 \mathrm{~m}^{2}$, randomly allocated in each plot, were used. All forage present inside these sampling frames was collected at the time after defoliation of the respective treatment (at 10 or $20 \mathrm{~cm}$ from the ground). On average, 'Survenola' digit grass managed with 40/10, $40 / 20,50 / 10$ and $50 / 20 \mathrm{~cm}$ defoliation strategies had $14,20,12$, and 15 defoliations, respectively, over the experimental period. Samples were divided into two subsamples. The first subsample, composed by the entire plant, was weighed before and after drying in a forced-air drier at $55^{\circ} \mathrm{C}$ for 72 hours. The second subsample was separated in leaf blades, stems, and dead forage, and each part was dried in a forced-air similarly to the first subsample conditions. Thus, the total accumulation $\left(\mathrm{kg} \mathrm{ha}^{-1}\right)$ of forage and the morphological components of 'Survenola' digit grass were determined. 
At the start of the experiment, in July 2017, two tussocks were marked at random per plot (Montagner et al., 2012). All tillers within each tussock were counted and marked by different colored plastic-coated wire. After each defoliation, all marked tillers were counted again; new tillers were marked with a different color from that used in the previous markings, and the wires around dead tillers were removed. This allowed of the elaboration of the survival diagrams for each age cohort, and to calculate the following parameters: appearance rate [(flowered tillers/ total live tillers at the previous tagging $) \times 100 \times 30$ ]; mortality rate [(dead tillers/ total live tillers at the previous tagging $) \times 100 \mathrm{x}$ $30]$; survival rate (100 - tiller mortality rate) according with Bahmani et al. (2003); and tiller population stability index [(tiller survival rate + tiller appearance rate)/ 100] according Duchini et al. (2018). The tiller density (number of basal and aerial tillers) was determined by counting the tillers contained in a metal frame $\left(0.23 \mathrm{~m}^{2}\right)$ allocated in three representative areas per plot, whenever plant canopy reached the height for pre-defoliation (Sbrissia et al., 2020).

The survival diagrams for each age cohort of 'Survenola' digit grass was presented descriptively. Forage, leaf, stem, and dead forage accumulation data, as well as the tiller appearance, mortality and survival rates, and the stability index of tiller population were subjected to the analysis of variance, using the Proc Mixed of SAS software version 8.2 (SAS Institute Inc, Cary, NC, USA). Akaike's information criteria (AIC) were applied to choose the matrix of variance (Wolfinger, 1993) and detect the effects of defoliation strategies, insolation periods, and interactions. Defoliation strategies, insolation periods, and interactions were considered as fixed factors, and blocks and their interactions as the random effects (Littell et al., 2000). The means were estimated using the Proc LSMeans and compared by the Tukey's test, at $5 \%$ probability.

\section{Results and Discussion}

The defoliation strategies 40/10, 40/20, 50/10, and $50 / 20 \mathrm{~cm}$ provided defoliation intensities of their initial heights of 75, 50, 80, and 60\%, respectively (Figure 2). As defoliation intensities decreased, the number of harvests were reduced, during the experimental period, as follows: 20 harvests for DS 40/20 cm (11 and 9 harvests, in the periods of higher and lower insolation, respectively); 15 harvests for DS 50/20 cm (9 and 6 harvests, in the periods of higher e lower insolation, respectively); 14 harvests for DS $40 / 10 \mathrm{~cm}$ (8 and 6 harvests, in the periods of higher e lower insolation, respectively); and only 12 harvests for DS 50/10 cm (7 and 5 harvests, in the periods of higher elower insolation, respectively). The increase of defoliation intensity results in a longer regrowth interval (Chapman, 2016), which decreases the number of possible defoliations. It can also be observed that no age cohort stood out in the proposed defoliation strategies.

Appearance, mortality, survival, and basal and aerial stability of tillers were affected by the interaction between defoliation strategies and insolation periods (Table 1). 'Survenola' grass had a higher appearance rate of basal tiller, during the higher insolation period for the DS 40/10 and 50/10 cm. However, during the lower insolation period, this effect was higher for the DS of $40 / 20$ and $50 / 20 \mathrm{~cm}$. Still, in this period, the mortality rate of tillers was higher for the DS of $40 / 20$ $\mathrm{cm}$, and the same pattern was observed for the DS of $50 / 20 \mathrm{~cm}$ in the lower insolation period. During the higher insolation period, the mortality rate of basal tillers was higher for the DS $40 / 20$ and $50 / 10 \mathrm{~cm}$; however, during the lower insolation period, it was higher for DS 40/10, 50/10 and 50/20 cm.

For aerial tillers, the appearance rate was higher in the DS $40 / 20 \mathrm{~cm}$, and the tiller mortality rate was higher in the DS 40/10 and 50/10 cm during the higher insolation period. However, under lower insolation, a reduction in the intensity of defoliation increased the rate of appearance and mortality of aerial tillers (Table 1).

Plants modify their growth patterns due to luminosity, fertilization, water availability, and the pasture management adopted. After defoliation, the growth of forage plants occurs through the growth of remaining tiller leaves, as well as the emergence of new tillers (Lemaire \& Chapman, 1996). Therefore, a higher defoliation intensity removes a larger amount of forage (Martins et al., 2021), which reduces the residual leaf area index, increasing the quality of light reaching the base of the canopy (Silva \& Nascimento Júnior, 2007). In the present work, the higher defoliation intensity and the reducing of residual leaf area index stimulated the rate of appearance of basal tillers, in the defoliation strategies $40 / 10$ ( $75 \%$ of their initial heights)

Pesq. agropec. bras., Brasília, v.55, e01602, 2020

DOI: 10.1590/S1678-3921.pab2020.v55.01602 

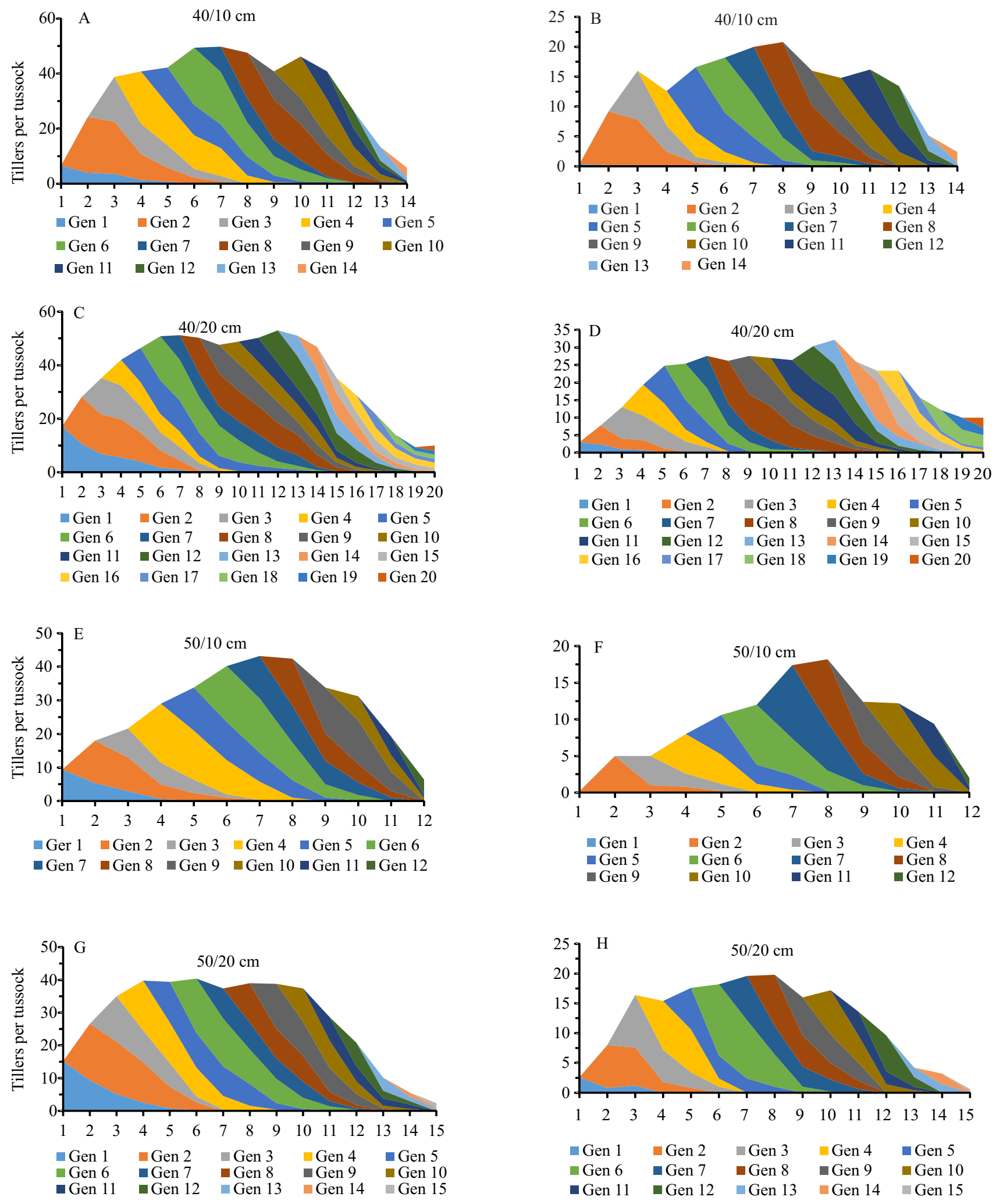

Figure 2. Survival diagrams for each age cohort of tillers of 'Survenola' digit grass (Digitaria eriantha) subjected to intermittent defoliation strategies: 40/10 cm, basal (A) and aerial (B); 40/20 cm, basal (C) and aerial (D); 50/10 cm basal (E) and aerial $(\mathrm{F})$; and 50/20 $\mathrm{cm}$ basal $(\mathrm{G})$ and aerial $(\mathrm{H})$. Gen, tiller generation. 
and $50 / 10$ ( $80 \%$ of their initial heights), in the period of higher insolation. This same pattern occurred for the tiller mortality rate. Removal of forage in more intense defoliation certainly caused a greater tiller renewal and, consequently, a higher mortality rate.

In turn, the intensity reduction of defoliation, especially in the period of lower insolation, stimulated the appearance and mortality of aerial tillers. According to Santos et al. (2014), the longer stem length remaining after defoliation, the greater the number of axillary nodes and buds that can be used for the development of aerial tillers, which may explain the higher rates of appearance of aerial tillers recorded in the defoliation of DS 40/20 cm.

The tiller population obtained a stability index close to 1 , which indicates its stability (Table 1). Variations of stability index for tiller population in the pasture is due to a natural process that depends on several factors (Caminha et al., 2010). Values higher than 1 indicate that survival rates associated with tiller appearance compensate the mortality, culminating in the population increase. However, values lower than 1 suggest a higher mortality when compared to survival rates and tiller rise, that is, the population is not stable. Values similar to 1 means that population is stable, or indicate that there is no growth or reduction of tiller population (Bahmani et al., 2003).

In this context, the defoliation strategies of $40 / 10$ and $50 / 10 \mathrm{~cm}$ showed populations of basal tillers less stable, with greater population growth in the period of higher insolation, and greater reduction in the period of lower insolation. These variations are probably the

Table 1. Rates of appearance, mortality and survival, and stability indices of basal and aerial tillers of 'Survenola' digit grass (Digitaria eriantha) subjected to intermittent defoliation strategies during periods of higher and lower insolation ${ }^{(1)}$.

\begin{tabular}{|c|c|c|c|c|c|c|}
\hline \multirow[t]{2}{*}{ Insolation period } & \multicolumn{4}{|c|}{ Defoliation strategies } & \multirow[t]{2}{*}{ SEM } & \multirow[t]{2}{*}{ p-value } \\
\hline & $40 / 10 \mathrm{~cm}$ & $40 / 20 \mathrm{~cm}$ & $50 / 10 \mathrm{~cm}$ & $50 / 20 \mathrm{~cm}$ & & \\
\hline & \multicolumn{6}{|c|}{ Basal tiller appearance rate (tiller 100 tiller $^{-1}$ per 30 -day-period) } \\
\hline Higher insolation & $43.47 \mathrm{Aa}$ & $38.51 \mathrm{Ba}$ & $45.26 \mathrm{Aa}$ & $39.38 \mathrm{Ba}$ & \multirow{2}{*}{1.100} & \multirow{2}{*}{$<0.00001$} \\
\hline Lower insolation & $22.66 \mathrm{Bb}$ & $29.96 \mathrm{Ab}$ & $21.54 \mathrm{Bb}$ & $29.95 \mathrm{Ab}$ & & \\
\hline & \multicolumn{6}{|c|}{ Basal tiller mortatily rate (tiller 100 tiller $^{-1}$ per 30 -day-period) } \\
\hline Higher insolation & $29.39 \mathrm{Bb}$ & $35.56 \mathrm{Aa}$ & $28.84 \mathrm{Ba}$ & $30.21 \mathrm{Bb}$ & \multirow{2}{*}{1.079} & \multirow{2}{*}{0.0008} \\
\hline Lower insolation & $34.17 \mathrm{Ba}$ & $31.84 \mathrm{BCb}$ & $29.98 \mathrm{Ca}$ & $39.85 \mathrm{Aa}$ & & \\
\hline & \multicolumn{6}{|c|}{ Basal tiller survival rate (tiller 100 tiller $^{-1}$ per 30 -day-period) } \\
\hline Higher insolation & $70.60 \mathrm{Aa}$ & $64.44 \mathrm{Ba}$ & $71.15 \mathrm{Aa}$ & $69.78 \mathrm{Aa}$ & \multirow{2}{*}{1.079} & \multirow{2}{*}{0.0008} \\
\hline Lower insolation & $65.82 \mathrm{Bb}$ & $68.15 \mathrm{ABa}$ & $70.01 \mathrm{Aa}$ & $60.14 \mathrm{Cb}$ & & \\
\hline & \multicolumn{6}{|c|}{ Basal tiller stability index } \\
\hline Higher insolation & $1.14 \mathrm{ABa}$ & $1.03 \mathrm{Ca}$ & $1.16 \mathrm{Aa}$ & $1.09 \mathrm{Ba}$ & \multirow{2}{*}{0.018} & \multirow{2}{*}{$<0.0001$} \\
\hline Lower insolation & $0.88 \mathrm{Bb}$ & $0.98 \mathrm{Aa}$ & $0.92 \mathrm{Bb}$ & $0.90 \mathrm{Bb}$ & & \\
\hline & \multicolumn{6}{|c|}{ Aerial tiller appearance rate (tiller 100 tiller $^{-1}$ per 30 -day-period) } \\
\hline Higher insolation & $64.87 \mathrm{Ba}$ & $83.82 \mathrm{Aa}$ & $64.35 \mathrm{Ba}$ & $65.69 \mathrm{Ba}$ & \multirow{2}{*}{2.222} & \multirow{2}{*}{0.0005} \\
\hline Lower insolation & $38.20 \mathrm{Bb}$ & $52.45 \mathrm{Ab}$ & $18.58 \mathrm{Cb}$ & $46.21 \mathrm{Ab}$ & & \\
\hline & \multicolumn{6}{|c|}{ Aerial tiller mortatily rate (tiller 100 tiller $^{-1}$ per 30 -day-period) } \\
\hline Higher insolation & $52.81 \mathrm{Aa}$ & $50.42 \mathrm{Ab}$ & $41.21 \mathrm{Ba}$ & $43.85 \mathrm{Bb}$ & \multirow{2}{*}{1.792} & \multirow{2}{*}{$<0.0001$} \\
\hline Lower insolation & $43.94 \mathrm{Cb}$ & $62.15 \mathrm{Aa}$ & $35.05 \mathrm{Db}$ & $51.38 \mathrm{Ba}$ & & \\
\hline & \multicolumn{6}{|c|}{ Aerial tiller survival rate (tiller 100 tiller-1 $^{-1}$ per 30 -day-period) } \\
\hline Higher insolation & $47.19 \mathrm{Bb}$ & $49.57 \mathrm{Ba}$ & $58.79 \mathrm{Ab}$ & $56.14 \mathrm{Aa}$ & \multirow{2}{*}{1.792} & \multirow{2}{*}{$<0.0001$} \\
\hline Lower insolation & $56.06 \mathrm{Ba}$ & $37.84 \mathrm{Db}$ & 64.94Aa & $48.62 \mathrm{Cb}$ & & \\
\hline & \multicolumn{6}{|c|}{ Aerial tiller stability index } \\
\hline Higher insolation & $1.11 \mathrm{Ca}$ & $1.33 \mathrm{Aa}$ & $1.23 \mathrm{Ba}$ & $1.22 \mathrm{Ba}$ & \multirow{2}{*}{0.022} & \multirow{2}{*}{$<0.0001$} \\
\hline Lower insolation & $0.94 \mathrm{Ab}$ & $0.90 \mathrm{ABb}$ & $0.83 \mathrm{Bb}$ & $0.95 \mathrm{Ab}$ & & \\
\hline
\end{tabular}

${ }^{(1)}$ Means followed by equal letters, uppercases in the lines and lowercases in the columns, do not differ by Tukey's test, at 5\% probability. SEM, standard error of the mean. 
result of the greater forage removal caused by these strategies. The stability of the population of aerial tillers showed a greater variation in relation to the basal ones. This occurred certainly because aerial tillers have a short life, since they are located in the grazable stratum, which facilitates their removal during defoliation (Santos et al., 2014), as well as they are highly dependent on basal tillers for nutrition, water supply, and support (Silva et al., 2017). Within the evaluated period, no strategy contributed to the degradation of the forage plant (Sousa et al., 2019). Thus, the choice of the defoliation strategy used could be based on other criteria, such as production, or quality of the forage produced.

In turn, the stability index of the population of basal and aerial tillers decreased in the period of lower insolation, regardless of the defoliation strategy used. These variations between growing seasons were also recorded by Caminha et al. (2010). According to these authors, this variation occurs due to changes in the availability of growth factors, such as temperature, light, and water.

The density of basal, aerial, and total tillers was affected by defoliation strategies $(p=0.008 ; p=0.0019$ and $\mathrm{p}=0.0047)$ and insolation period $(\mathrm{p}<0.0001)$ (Figure 3). 'Survenola' digit grass showed the highest density of basal, aerial, and total tillers for the DS of $40 / 20 \mathrm{~cm}$ (Figure $3 \mathrm{~A}$ ). It is possible that the higher post-defoliation height (20 versus $10 \mathrm{~cm}$ ) favored the maintenance of basal tillers, which were maximized by using a lower pre-defoliation height (40 versus $50 \mathrm{~cm}$ ). The height increase of the canopy allows of a greater light interception and, consequently, the intraspecific competition for light (Silva \& Nascimento Júnior, 2007) which triggers a process of tiller death, in a process balance between the number and weight (size) of tillers (Sbrissia \& Silva, 2008). In fact, the $50 / 20 \mathrm{~cm}$ defoliation strategy showed a lower population density of basal tillers than the DS $40 / 20 \mathrm{~cm}$, indicating that the interruption of regrowth at the height of $50 \mathrm{~cm}$ caused a greater competition for light.

It is also possible that the basal tillers of the treatments with $20 \mathrm{~cm}$ height after defoliation, due to less forage removal, had reached an advanced stage of development, which may have favored the activation of axillary buds and, consequently, favored the aerial tillering that can be an important competition strategy for forage plants. Despite being generally short-lived and highly dependent on basal tillers for nutrition, water supply, and support (Silva et al., 2017), aerial tillers have a high share of leaves and have softer stems, allowing of a better nutritional value, in addition to being located in the grazable stratum, which facilitates their apprehension by animals for forage (Santos et al., 2014). In fact, aerial tillers of 'Survenola' digit
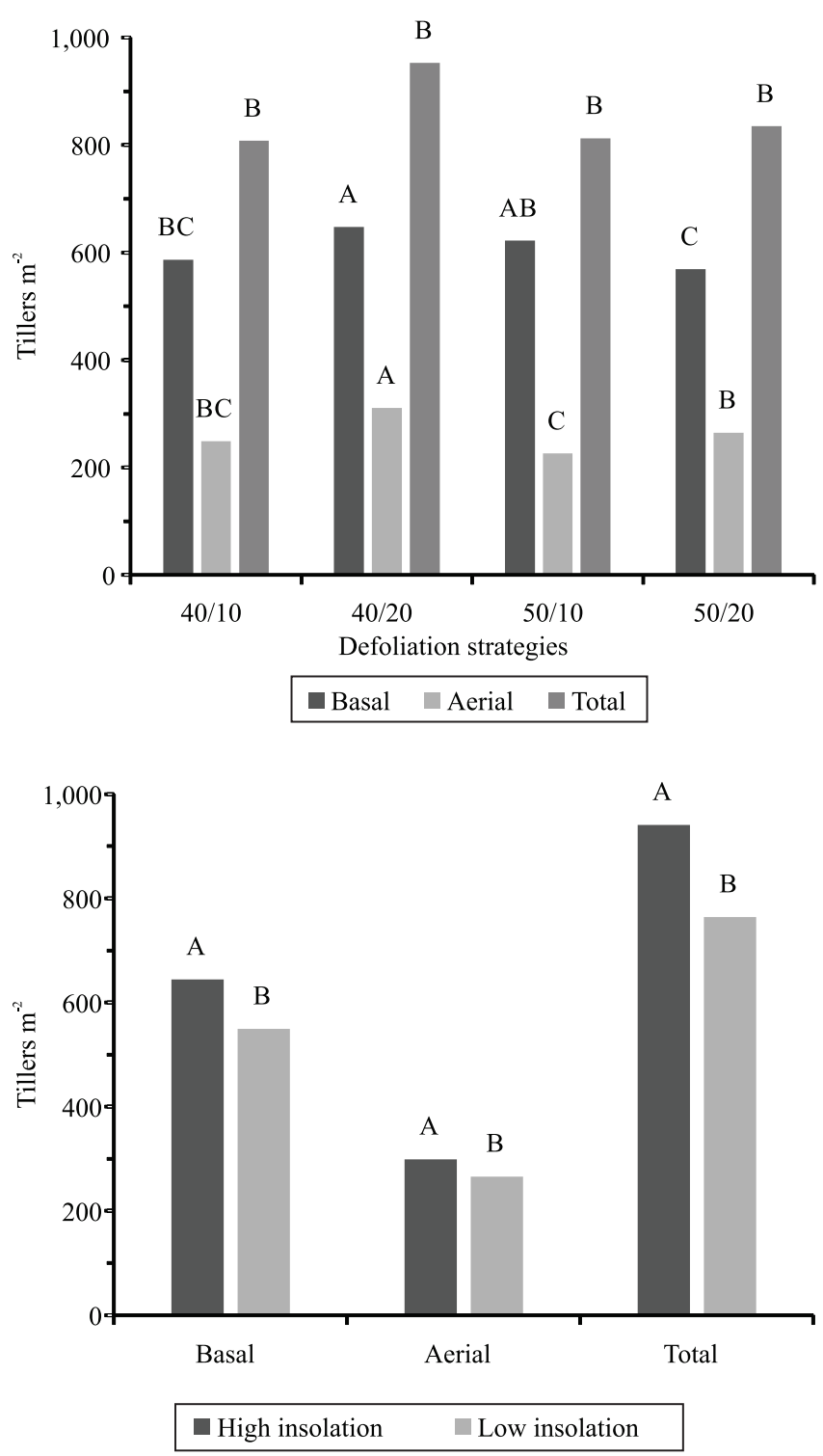

Figure 3. Basal, aerial, and total tiller density of 'Survenola' digit grass (Digitaria eriantha) subjected to intermittent defoliation strategies, during periods of high and low insolation. Means followed by equal letters, do not differ by Tukey's test, at $5 \%$ probability. 
grass contribute accumulatively 15 to $25 \%$ of the total forage, depending on the management (Gusmão Filho et al., 2020), and they are an important growth strategy for this plant. In turn, the 40/10 and 50/10 cm defoliation strategies favored the canopy renewal, due to the defoliation intensity, which possibly favored the formation of basal tillers to the detriment of aerial tillers in relation to the $50 / 20 \mathrm{~cm}$ strategy.

A higher density of basal, aerial, and total tillers was recorded in the period of higher insolation (Figure $3 \mathrm{~B}$ ). The better availability of climatic factors (light, temperature, and precipitation) stimulates the appearance and mortality of tillers, which reduces the survival and increases the number of generations of tillers by this time (Silva et al., 2015). Despite their survival increase under climatic conditions of low light and lower temperatures, tillers were not able to compensate for the reduction of appearance rate and, consequently, they undergone a reduction of population density. Thus, the monitoring of changes of the population density of tillers, when associated with defoliation strategy and time of year, allows of the identification of the best management conditions to optimize plant growth (Fialho et al., 2012).

The total forage and leaf blade accumulation were affected by the interaction between defoliation strategies and insolation period (Table 2). 'Survenola' digit grass had a greater accumulation during the higher insolation period. Defoliation strategies that resulted in lower defoliation intensity of 50\% (DS 40/20 cm) and $60 \%$ (DS $50 / 20 \mathrm{~cm}$ ) caused a greater total forage and leaf blade accumulation than the intensities of $75 \%$ (DS $40 / 10 \mathrm{~cm}$ ) and $80 \%$ of their initial heights (DS 50/10 cm). Martins et al. (2021) also registered a reduction of the forage production capacity due to the increase of the defoliation intensity.

Plants can modify their growth habits due to environmental changes, which is known as phenotypic plasticity. In the case of tropical grasses, these alterations are a result of the canopy management (Lemaire \& Agnusdei, 2000). The DS 40/20 cm of 'Survenola' digit grass had a higher accumulation of total forage due, in part, to the number of basal, aerial, and total tillers (Figure $3 \mathrm{~A}$ ). In addition, leniently defoliated pastures could have their forage production increased due to the shorter regrowth interval (Chapman, 2016). In fact, the DS 40/20 cm defoliation strategy showed the higher defoliation cycle (Figure 2), which directly contributed to the greatest accumulation of forage and leaf blades, especially in the period of higher insolation, when the climatic conditions (brightness and temperature) favored photosynthesis (Silva et al., 2015).

The defoliation strategies and insolation periods also affected stems and dead forage accumulation. The DS 40/20 cm showed the lowest value for stem accumulation (Figure $4 \mathrm{~A}$ ), while this same strategy had the highest value for dead forage (Figure $4 \mathrm{C}$ ). Overall, higher and lower values were observed for stems and dead forage accumulation, respectively, during the higher insolation period (Figure 4 B and D).

The combination between lower defoliation frequency $(40 \mathrm{~cm})$ and higher post-defoliation residual $(20 \mathrm{~cm})$ stimulated the plant regrowth. The regrowth process is a result of an increase of the foliar area index by leaf blade appearance and growth of young tillers (Silva et al., 2015). A higher post-defoliation residual reduces the removal of aerial meristems and increases the foliar area index with a higher photosynthesis

Table 2. Accumulation of total forage and leaf blades of 'Survenola' digit grass (Digitaria eriantha) subjected to intermittent defoliation strategies, during periods of higher and lower insolation ${ }^{(1)}$.

\begin{tabular}{|c|c|c|c|c|c|c|}
\hline \multirow[t]{2}{*}{ Insolation period } & \multicolumn{4}{|c|}{ Defoliation strategies $(\mathrm{cm})$} & \multirow[t]{2}{*}{ SEM } & \multirow[t]{2}{*}{ p-value } \\
\hline & $40 / 10$ & $40 / 20$ & $50 / 10$ & $50 / 20$ & & \\
\hline \multicolumn{7}{|c|}{ Total forage accumulation $\left(\mathrm{kg} \mathrm{ha}^{-1}\right)$} \\
\hline Higher insolation & $15,188 \mathrm{BCa}$ & $17,019 \mathrm{Aa}$ & $14,190 \mathrm{Ca}$ & $15,597 \mathrm{Ba}$ & \multirow{2}{*}{440.4} & \multirow{2}{*}{0.0340} \\
\hline Lower insolation & $9,174 \mathrm{Bb}$ & $10,904 \mathrm{Ab}$ & $8,803 \mathrm{Bb}$ & $11,232 \mathrm{Ab}$ & & \\
\hline \multicolumn{7}{|c|}{ Leaf blade accumulation $\left(\mathrm{kg} \mathrm{ha}^{-1}\right)$} \\
\hline Higher insolation & $8,810 \mathrm{BCa}$ & $11,675 \mathrm{Aa}$ & $7,924 \mathrm{Ca}$ & $9,839 \mathrm{Ba}$ & \multirow{2}{*}{344.6} & \multirow{2}{*}{0.0277} \\
\hline Lower insolation & $5,232 \mathrm{Bb}$ & $7,424 \mathrm{Ab}$ & $4,895 \mathrm{Bb}$ & $7,144 \mathrm{Ab}$ & & \\
\hline
\end{tabular}

${ }^{(1)}$ Means followed by equal letters, uppercases in the lines and lowercases in the columns, do not differ by Tukey's test, at 5\% probability. SEM, standard error of the mean. 
efficiency, which enhance the pasture regrowth (Taiz et al., 2017). The lower defoliation frequency $(40 \mathrm{~cm})$ reduces the intraspecific competition for light, which also reduces the stem accumulation. It is important to highlight that a higher stem accumulation is not desirable, since stems are less nutritive than leaf blades and reduce the animal performance (Gimenes et al., 2011) because it is a physical barrier to biting (Difante et al., 2010).
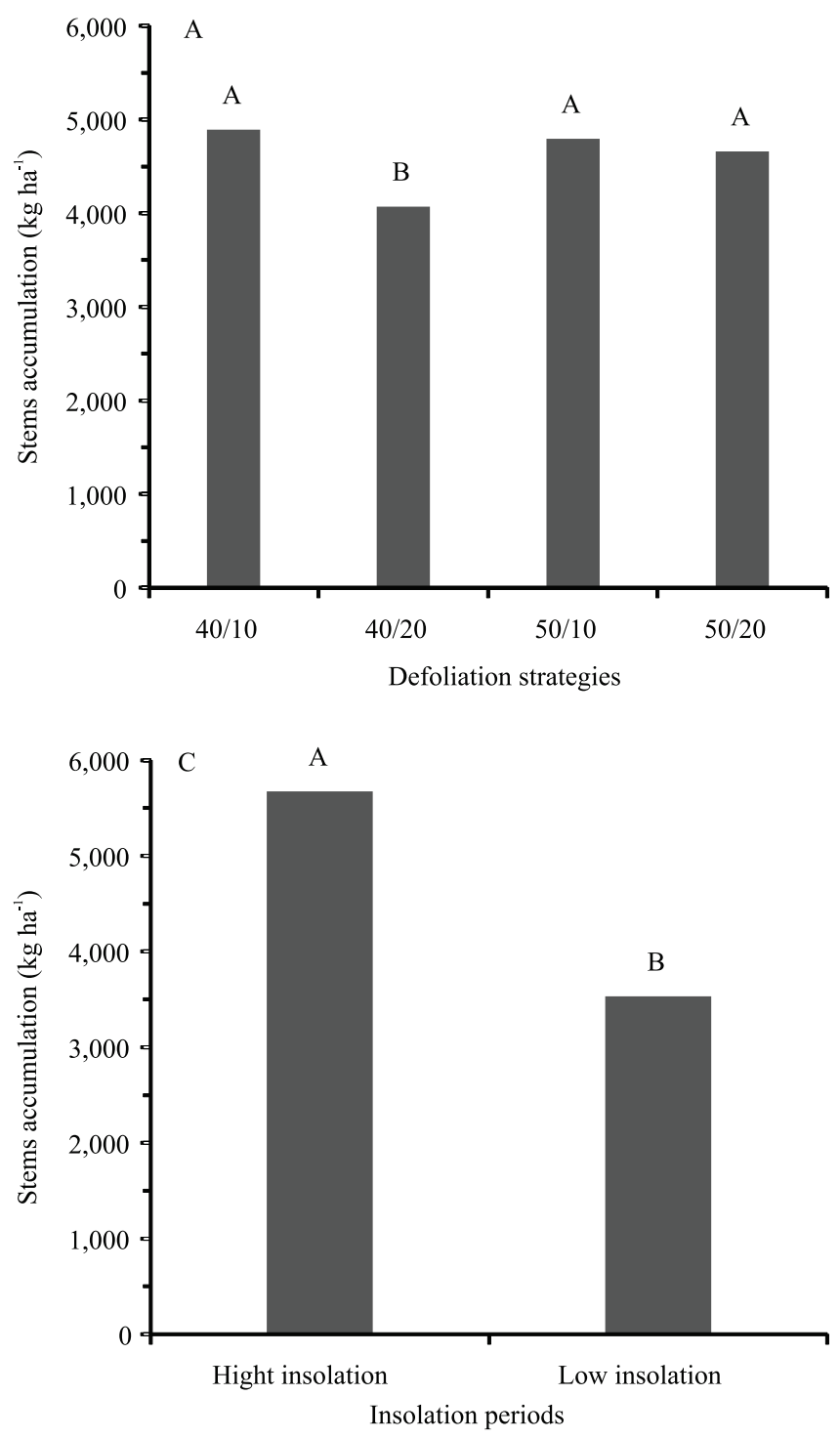

In this sense, the DS of $40 / 20 \mathrm{~cm}$ approach was the best choice for 'Survenola' digit grass management, as it resulted in the higher rates of appearance and mortality of basal and aerial tillers (Table 1), indicating a tiller regrowth (Figures $2 \mathrm{C}$ and $\mathrm{D}$ ).

The DS of $50 / 10 \mathrm{~cm}$ is probably the less recommended strategy because it resulted in the decrease of the tiller appearance and in higher mortality rates of basal and aerial tillers (Figures $2 \mathrm{E}$ and F).
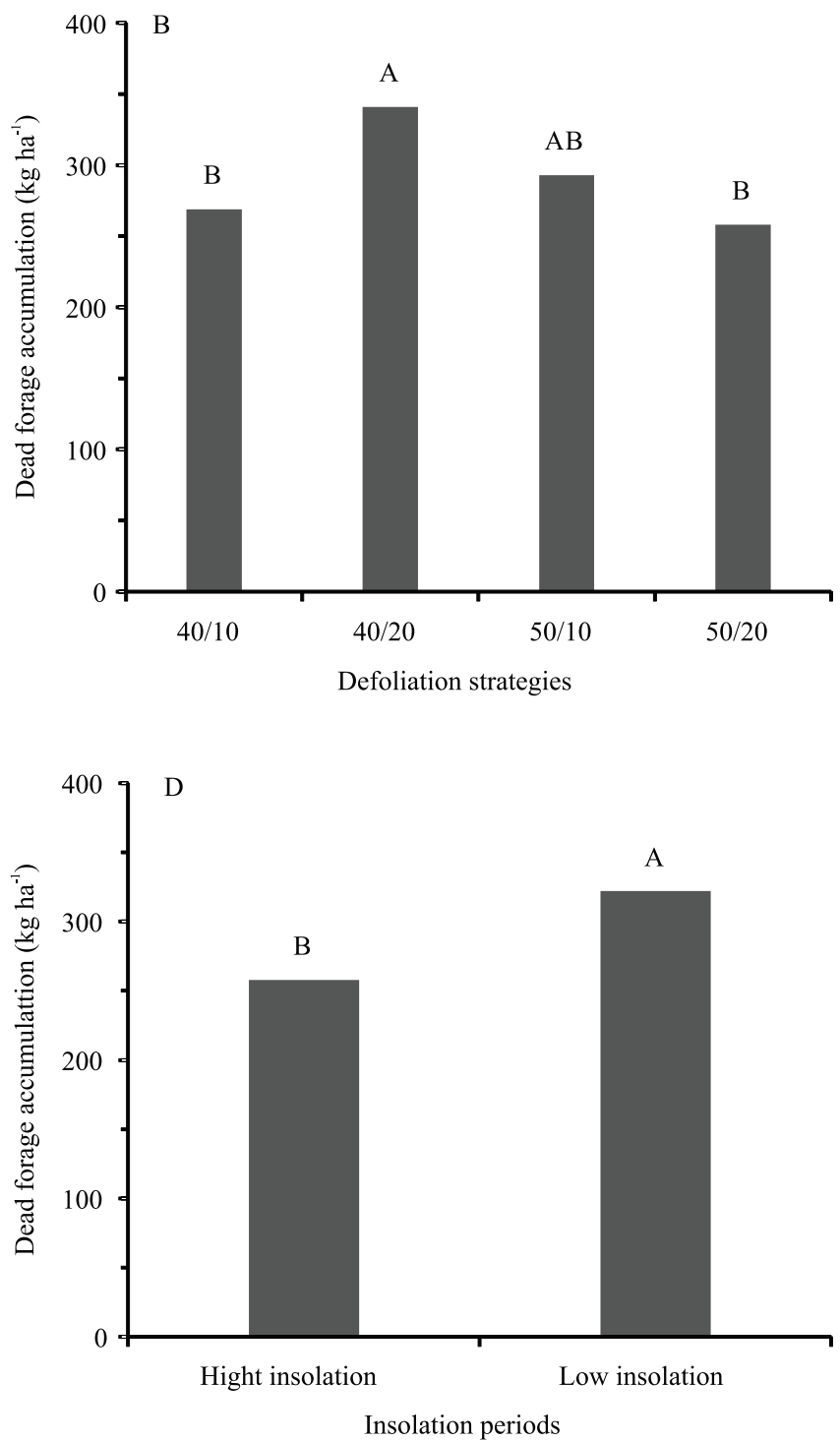

Figure 4. Stems and dead forage accumulations of 'Survenola' digit grass (Digitaria eriantha) subjected to intermittent defoliation strategies (A and B), during periods of high and low insolation (C and D). Means followed by equal letters, do not differ by Tukey's test, at $5 \%$ probability. 


\section{Conclusions}

1. Defoliation strategies and insolation can change the growth and accumulation of 'Survenola' digit grass (Digitaria eriantha) tillers, which occur mostly under higher insolation periods.

2. In the pre- and post-defoliation of DS $40 / 20 \mathrm{~cm}$, 'Survenola' digit grass shows the highest number of defoliation cycles, with the highest accumulation of forage and leaf blades, and the lowest accumulation of stems. In addition, this defoliation strategy favors the population density of tillers.

\section{Acknowledgments}

To Coordenação de Aperfeiçoamento de Pessoal de Nível Superior (Capes), for partial support to the study (Finance Code 001); to Conselho Nacional de Desenvolvimento Científico e Tecnológico (CNPq) and to Fundação de Apoio à Pesquisa e à Inovação Tecnológica do Estado de Sergipe (Fapitec), for financial support.

\section{References}

BAHMANI, I.; THOM, E.R.; MATTHEW, C.; HOOPER, R.J.; LEMAIRE, G. Tiller dynamics of perennial ryegrass cultivars derived from different New Zealand ecotypes: effects of cultivar, season, nitrogen fertiliser, and irrigation. Australian Journal of Agricultural Research, v.54, p.803-817, 2003. DOI: https://doi.org/10.1071/AR02135.

CAMINHA, F.O.; SILVA, S.C. da; PAIVA, A.J.; PEREIRA, L.E.T.; MESQUITA, P. de; GUARDA, V.D.A. Estabilidade da população de perfilhos de capimmarandu sob lotação contínua e adubação nitrogenada. Pesquisa Agropecuária Brasileira, v.45, p.213-220, 2010. DOI: https://doi.org/10.1590/S0100204X2010000200013.

CARVALHO, A.L.S.; MARTUSCELLO, J.A.; ALMEIDA, O.G. de; BRAZ, T.G. dos S.; CUNHA, D. de N.F.V. da; JANK, L. Production and quality of Mombaça grass forage under different residual heights. Acta Scientiarum. Animal Sciences, v.39, p.143-148, 2017. DOI: https://doi.org/10.4025/actascianimsci. v39i2.34599.

CHAPMAN, D.F. Using ecophysiology to improve farm efficiency: application in temperate dairy grazing systems. Agriculture, v.6, art.17, 2016. DOI: https://doi.org/10.3390/ agriculture6020017.

COOK, B.G.; SCHULTZE-KRAFT, R. Botanical name changes nuisance or a quest for precision? Tropical Grasslands - Forrajes Tropicales, v.3, p.34-40, 2015. DOI: https://doi.org/10.17138/ TGFT(3)34-40.
CRUZ, N.T.; SOUSA, B.M. de L.; FAGUNDES, J.L.; BACKES, A.A.; GUSMÃO FILHO, J.D.; VILAS-BÔAS, R.T.; RIZATO, C.A.; BARBOSA, L.T. Herbage accumulation dynamics in digit grass subjected to defoliation frequencies. Semina: Ciências Agrárias, v.40, p.731-744, 2019. DOI: https://doi.org/10.5433/16790359.2019v40n2p731.

DIFANTE, G. dos S.; EUCLIDES, V.P.B.; NASCIMENTO JÚNIOR, D. do; SILVA, S.C. da; BARBOSA, R.A.; TORRES JÚNIOR, R.A. de A. Desempenho e conversão alimentar de novilhos de corte em capim-tanzânia submetido a duas intensidades de pastejo sob lotação rotativa. Revista Brasileira de Zootecnia, v.39, p.33-41, 2010. DOI: https://doi.org/10.1590/ S1516-35982010000100005.

DUCHINI, P.G.; GUZATTI, G.C.; ECHEVERRIA, J.R.; AMÉRICO, L.F.; SBRISSIA, A.F. Experimental evidence that the perennial grass persistence pathway is linked to plant growth strategy. PloS ONE, v.13, e0207360, 2018. DOI: https://doi.org/10.1371/journal.pone.0207360.

FIALHO, C.A.; SILVA, S.C. da; GIMENES, F.M. de A.; GOMES, M.B.; BERNDT, A.; GERDES, L. Tiller population density and tillering dynamics in marandu palisade grass subjected to strategies of rotational stocking management and nitrogen fertilization. Acta Scientiarum. Animal Sciences, v.34, p.245-251, 2012. DOI: https://doi.org/10.1590/S1516-35982010000100005.

GIMENES, F.M. de A.; SILVA, S.C. da; FIALHO, C.A.; GOMES, M.B.; BERNDT, A.; GERDES, L.; COLOZZA, M.T. Ganho de peso e produtividade animal em capim-marandu sob pastejo rotativo e adubação nitrogenada. Pesquisa Agropecuária Brasileira, v.46, p.751-759, 2011. DOI: https://doi.org/10.1590/ S0100-204X2011000700011.

GUSMÃO FILHO, J.D. Digitaria eriantha cv. Survenola submetido à alturas de desfolhação. 2018. 60p. Tese (Doutorado) - Universidade Estadual do Sudoeste da Bahia, Itapetinga.

GUSMÃO FILHO, J.D.; FRIES, D.D.; SOUSA, B.M. de L.; FAGUNDES, J.L.; BACKES, A.A.; DIAS, D.L.S.; PINHEIRO, S.S.C.; TEIXEIRA, F.A. Growth dynamics and senescence of digit grass as a response to several canopy heights. Revista Mexicana de Ciencias Pecuarias, v.11, p.38-52, 2020. DOI: https://doi.org/10.22319/rmcp.v11i1.4913.

LEMAIRE, G.; AGNUSDEI, M. Leaf tissue turnover and efficiency of herbage utilization. In: LEMAIRE, G.; HODGSON, J.; MORAES, A. de; CARVALHO, P.C. de F.; NABINGER, C. (Ed.). Grassland ecophysiology and grazing ecology. Wallingford: CAB International, 2000. p.265-288. DOI: https://doi.org/10.1079/9780851994529.0265.

LEMAIRE, G.; CHAPMAN, D. Tissue flows in grazed plant communities. In: HODGSON, J.; ILLIUS, A.W. (Ed.). The ecology and management of grazing systems. Wallingford: CAB International, 1996. p.3-36.

LITTELL, R.C.; PENDERGAST, J.; NATARAJAN, R. Modelling covariance structure in the analysis of repeated measures data. Statistics in Medicine, v.19, p.1793-1819, 2000. DOI: https://doi.org/10.1002/1097-0258(20000715)19:13<1793::AIDSIM482>3.0.CO;2-Q. 
MARTINS, C.D.M.; SCHMITT, D.; DUCHINI, P.G.; MIQUELOTO, T.; SBRISSIA, A.F. Defoliation intensity and leaf area index recovery in defoliated swards: implications for forage accumulation. Scientia Agricola, v.78, e20190095, 2021. DOI: https://doi.org/10.1590/1678-992x-2019-0095.

MONTAGNER, D.B.; NASCIMENTO JÚNIOR, D. do; VILELA, H.H.; SOUSA, B.M. de L.; EUCLIDES, V.P.B.; SILVA, S.C. da; CARLOTO, M.N. Tillering dynamics in pastures of guinea grass subjected to grazing severities under intermittent stocking. Revista Brasileira de Zootecnia, v.41, p.544-549, 2012. DOI: https://doi.org/10.1590/S1516-35982012000300010.

NAVARRO, L.; RODRÍGUEZ, I.; GONZÁLEZ, S.; TORRES, A. Umfolozi o pangola peluda: un pasto que comienza a ser cultivado. INIA Divulga, v.4, p.29-32, 2005.

SANTOS, H.G. dos; JACOMINE, P.K.T.; ANJOS, L.H.C. dos; OLIVEIRA, V.A. de; LUMBRERAS, J.F.; COELHO, M.R.; ALMEIDA, J.A. de; ARAUJO FILHO, J.C. de; OLIVEIRA, J.B. de; CUNHA, T.J.F. Sistema brasileiro de classificação de solos. 5.ed. rev. e ampl. Brasília: Embrapa, 2018. E-book.

SANTOS, M.E.R.; CASTRO, M.R.S.A. e; GOUVÊIA, S.C.; GOMES, V.M.; FONSECA, D.M. da; SANTANA, S.S. Contribuição de perfilhos aéreos e basais na dinâmica de produção de forragem do capim-braquiária após o pastejo diferido. Bioscience Journal, v.30, p.424-430, 2014. Suppl. 1.

SBRISSIA, A.F.; SCHMITT, D.; DUCHINI, P.G.; SILVA, S.C. da. Unravelling the relationship between a seasonal environment and the dynamics of forage growth in grazed swards. Journal of Agronomy and Crop Science, p.1-10, 2020. DOI: https://doi. org/10.1111/jac.12402.

SBRISSIA, A.F.; SILVA, S.C. da. Compensação tamanho/ densidade populacional de perfilhos em pastos de capimmarandu. Revista Brasileira de Zootecnia, v.37, p.35-47, 2008. DOI: https://doi.org/10.1590/S1516-35982008000100005.

SILVA, S.C. da; CHIAVEGATO, M.B.; PENA, K.S.; SILVEIRA, M.C.T.; BARBERO, L.M.; S. JUNIOR, S.J.; RODRIGUES, C.S.; LIMÃO, V.A.; PEREIRA, L.E.T. Tillering dynamics of Mulato grass subjected to strategies of rotational grazing management. Journal of Agricultural Science, v.155, p.1082-1092, 2017. DOI: https://doi.org/ https://doi.org/10.1017/S0021859617000223.

SILVA, S.C. da; NASCIMENTO JÚNIOR, D. do. Avanços na pesquisa com plantas forrageiras tropicais em pastagens: características morfofisiológicas e manejo do pastejo. Revista Brasileira de Zootecnia, v.36, p.122-138, 2007. Suplemento especial. DOI: https://doi.org/10.1590/S1516-35982007001000014.

SILVA, S.C. da; SBRISSIA, A.F.; PEREIRA, L.E.T. Ecophysiology of $\mathrm{C}_{4}$ forage grasses - understanding plant growth for optimising their use and management. Agriculture, v.5, p.598-625, 2015. DOI: https://doi.org/10.3390/agriculture5030598.

SOIL SURVEY STAFF. Soil taxonomy: a basic system of soil classification for making and interpreting soil surveys. $2^{\text {nd }}$ ed. Washington: USDA, NRCS, 1999. 866p.

SOUSA, B.M. de L.; RIZATO, C.A.; FAGUNDES, J.L.; FONTES, P.T.N.; BACKES, A.A.; OLIVEIRA JÚNIOR, L.F.G. de; CRUZ, N.T.; NASCIMENTO, C.S. do. Tillering dynamics of digit grass subjected to different defoliation frequencies. Pesquisa Agropecuária Brasileira, v.54, e00668, 2019. DOI: https://doi.org/10.1590/s1678-3921.pab2019.v54.00668.

SOUZA, L.J.N.; SANTOS, D.B.O.; FAGUNDES, J.L.; SOUZA, B.M.L.; BACKES, A.A.; OLIVEIRA JÚNIOR, L.F.G.; SANTOS, A.D.F.; MOREIRA, A.L. Morfogênese do capim faixa-branca submetido a adubação nitrogenada. Boletim de Indústria Animal, v.73, p.281-289, 2016. DOI: https://doi.org/10.17523/bia. v73n4p281.

TAIZ, L.; ZEIGER, E.; MOLLER, I.M.; MURPHY, A. Fisiologia e desenvolvimento vegetal. 6.ed. Porto Alegre: Artmed, 2017. $858 \mathrm{p}$.

WOLFINGER, R.D. Covariance structure selection in general mixed models. Communications in Statistics Simulation and Computation, v.22, p.1079-1106, 1993. DOI: https://doi.org/10.1080/03610919308813143. 